\title{
Comparative bioassay of silver nanoparticles and malathion on infestation of red flour beetle, Tribolium castaneum
}

\author{
Alif Alisha A S and Thangapandiyan $\mathrm{S}^{*}$
}

\begin{abstract}
Background: Insecticide resistance is the major threat in pest control management. Formulation with silver nanoparticle can be used as an alternative method to overcome these problems. Nanoparticles can provide a cheap and reliable source against Tribolium castaneum. The primary aim of our study is to compare the insecticidal efficacy of nanoparticles with commercial insecticide malathion.

Results: Due to the problems associated with the indiscriminate use of synthetic insecticides which promote the insect resistance, it is necessary to give an extra impulse to search alternative ways to control this pest. Silver nanoparticle can provide an accurate solution. In this study, the silver nanoparticles were synthesized, characterized and tested against the Tribolium castaneum. Characterization of the silver nanoparticles was done using ultraviolet-visible (UV-Vis) spectroscopy, $X$-ray diffraction (XRD), scanning electron microscopy (SEM), and energy dispersive spectroscopy (EDS). The study was conducted to compare the mortality rate, ovipositional deterrent, repellent activity and antifeedent activity of different concentration of malathion, silver nanoparticles and the mixed suspension of silver nanoparticles and malathion against Tribolium castaneum. Results of all the assays clearly showed that the combination of silver nanoparticles with malathion shows high insecticidal efficacy.
\end{abstract}

Conclusion: Development of resistance to the pesticide is acknowledged as the most serious problem in pest control. Nanotechnology can revolutionize agriculture and can provide a solution for pest management. The results from the study suggest that the silver nanoparticles have the pesticidal property which is an alternative solution for the insecticide resistance.

Keywords: Silver nanoparticle, Tribolium castaneum, Mortality test, Antifeedant assay, Repellent study, Oviposition deterrent

\section{Background}

India is an agro-based nation, and the economy is mainly determined by the agricultural productivity. Insects and pests increase the risks of spoilage of crops. They are the real threat to the agriculture fields as well as the post-harvesting grain crops. Damage caused by the insects affects the quality, the quantity and the commercial value of the products (Tagizadeh and Mohammadkhani, 2017). Worldwide losses in stored grains caused by insects have been estimated to be between 5 and $10 \%$ in temperate and $20-30 \%$ in tropics (Berhanu et

\footnotetext{
* Correspondence: stp.nano@gmail.com

Department of Zoology, PSG College of Arts and Science, Coimbatore, Tamilnadu, India
}

al. 2018). Post-harvesting grain crops are exposed to many insect pests. Post-harvest losses could be of quantitative or qualitative nature and can generally be reflected in several ways such as weight loss, nutritional, and monetary loss (FAO, 1983). Most of the grains are usually stored on farm or in large commercial grain elevator. Wheat crop is under threat of many environmental stresses, diseases, and insect pests which causes significant yield loses (Muhammad et al. 2018). Two major groups of insects such as Coleoptera (beetles) and Lepidoptera (moths and butterflies) comprises the most economically important post-harvest insect pests. The ruining of the grains by the beetles will seriously affect the germination ability and virtue of the product. The infestation by the beetle is mainly due to improper 
sanitation. Insects are controlled principally by the use of insecticides, but several commonly used chemicals are no longer recommended for use on stored grains because of their potential health hazards to humans; hence, there is a need for safer and effective methods of insect control.

Among the various beetles, Tribolium casteneum Herbst is the major beetle which infests the stored products. Tribolium casteneum is commonly called red flour beetle. It is a gregarious insect of cereal grains and other products. This insect causes a substantial loss in storage because of its highreproductive potential (Prakash et al. 1987). So the controlling of this beetle is necessary to prevent economic loss. To control these beetles, various fumigants and other synthetic insecticides are widely used. Currently, malathion has been used comprehensively for controlling red flour beetle, but now, it is not so effective against this pest due to the insect resistance (Horton, 1984). Malathion is less toxic to the mammals whereas the pesticide causes negative effects even to the non-targeted organisms including humans (Parkin et al. 1958). An alternative approach to the control of the Tribolium casteneum is necessary to prevent the infestation of the cereals and grains.

Nanotechnology has revolutionized the world with tremendous advancements in many fields of science like engineering, biotechnology, analytical chemistry, and agriculture (Sahayaraj Kitherian, 2017). Their use in crop protection is just in its infancy (Resham et al. 2015). Nanoparticles help to produce new pesticides, insecticides, and insect repellents. The use of nanomaterials in agriculture, especially for plant protection and production, is an underexplored research area. As the nanoparticles have a high-surface area to volume ratio, they can pass through the cell membranes of the insects and can harm them. Silver nanoparticles (AgNPs) are increasingly used in various fields, including medical, food, health care, industrial purposes, and the agricultural fields. They are the nanoparticles of the silver of which the size ranges between $1 \mathrm{~nm}$ and $100 \mathrm{~nm}$. The silver nanoparticle has many applications due to the large degree of commercialization. The potential of AgNPs has been widely utilized in nanomedicine, drug delivery, cosmetics, electronic application, and environmental protection (Murawala et al. 2014). The silver nanoparticles were fabricated using a chemical reduction method.

As insects are resistant to the majority of the insecticide, it is necessary to find an alternative to control these insects which is a major threat to the agricultural crops. Nanotechnology plays an important role in the agricultural field. Silver nanoparticles have the efficacy to act against the insects (Abduz et al. 2012, Marwa et al. 2017). The major aim of our study is to compare the mortality rate, ovipositional deterrent, antifeedent activity, and repellent activity of the various concentrations of the silver nanoparticle, malathion, and its synergistic effect against the Tribolium castaneum.

\section{Methods}

Insect rearing

The red flour beetle, Tribolium castaneum, were collected from the stock culture maintained in the Department of Entomology, TNAU, Coimbatore, India. Mass cultures were maintained in the glass jars $(1000 \mathrm{ml})$ and subcultures were in the beaker $(500 \mathrm{ml})$ with food medium and the temperature is maintained at $27 \pm 1{ }^{\circ} \mathrm{C}$. A standard mixture of whole wheat flour with powdered dry yeast of 19:1 was used as a food medium throughout the experiment (Mostafa et al. 2012).

\section{Fabrication of silver nanoparticles}

The silver nanoparticles (AgNPs) were fabricated using chemical reduction method (Thangapandiyan and Prema, 2012). One percent trisodium solution was added drop to drop to the $0.01 \mathrm{M}$ silver nitrate solution under vigorous heating and stirring until color change from colorless to pale yellow. Then, it was removed from heating element and allowed to cool. The solution was washed three times in double distilled water and once in ethanol solution. The supernatant of the reaction solution was discarded and particles were dried in a hot air oven at $60{ }^{\circ} \mathrm{C}$. The dried particles were used for further analysis.

\section{Characterization of silver nanoparticles}

The reduction of $\mathrm{Ag}^{+}$in solutions was monitored by measuring a UV-Vis spectrum at a resolution of $1 \mathrm{~nm}$ was performed on Shimadzu dual beam spectrophotometer (model UV-2000 Shimadzu). The colloidal solution containing silver nanoparticles were purified by repeated centrifugation at $12,000 \mathrm{rpm}$ for $20 \mathrm{~min}$. The supernatant of the reaction solution was discarded and particles were dried in a hot air oven at $60{ }^{\circ} \mathrm{C}$. The dried mixture was collected for determination of silver nanoparticles by a X'pert PROPAN X-Ray diffractometer operated at $40 \mathrm{kV}$ and a current of $30 \mathrm{~mA}$ with $\mathrm{Cu} \alpha$ radiation $\left(\lambda=1.54060 \mathrm{~A}^{\circ}\right)$. The diffraction intensities were recorded from $35^{\circ}$ to $79.93^{\circ}$ in $2 \theta$ angles. Morphology of the synthesized silver nanoparticles was investigated with the scanning electron microscope (JSM 35 CF JEOL) operated at a resolution of $60 \mathrm{~A}^{\circ}$ at $15 \mathrm{kv}$ magnification of $5.0 \mathrm{k}$. The scale was about $32 \mathrm{~mm}$ to $3.6 \mu \mathrm{m}$. Thin films of the sample were prepared on a carbon-coated copper grid by just dropping a small amount of the sample on the grid, extra solution was removed using a blotting paper and then the film on the SEM grid was allowed to dry by putting it under a 
mercury lamp for $5 \mathrm{~min}$. The qualitative as well as quantitative status of elements of the synthesized silver nanoparticles was analyzed by EDS instrument (JSM $35 \mathrm{CF}$ JEOL) in a resolution of $60 \AA$, operated at $15.0 \mathrm{kV}$ with a magnification of $5 \mathrm{~K}$.

\section{Mortality tests}

Different concentrations of malathion, silver nanoparticles, and the mixed suspension of malathion and the silver nanoparticles were mixed with the wheat grain at the concentration of $12.5 \mathrm{mg}, 25 \mathrm{mg}, 50 \mathrm{mg}$ of nanoparticles and $12.5 \mu \mathrm{l}, 25 \mu \mathrm{l}, 50 \mu \mathrm{l}$ of malathion and the mixed concentrations of the malathion and silver nanoparticles were prepared and added to $50 \mathrm{~g}$ of wheat grain infested with 20 adults of Tribolium castaneum. The mortality rate was noted after $24 \mathrm{~h}$ till the ninth day. The calculation of mortality rate was corrected according to Abbott's formula (Goswami et al. 2010):

$$
\mathrm{Mc}=(\mathrm{Mo}-\mathrm{Me} / 100-\mathrm{Me}) \times 100
$$

Where

Mo $=$ Observed mortality rate of treated adults (\%),

$\mathrm{Me}=$ Mortality rate of control (\%),

$\mathrm{Mc}=$ Corrected mortality rate $(\%)$

Mortality rate measurement

$=($ number of dead insects $/$ number of initial insects $)$ $\times 100$

\section{The ovipositional deterrent effect}

The ovipositional deterrent effects of malathion and silver nanoparticles were also tested. The malathion, silver nanoparticles, and the mixed suspension of malathion and silver nanoparticles were used at the rate of $50 \mathrm{ppm}$. In the $20 \mathrm{~g}$ of wheat with treated and untreated is infested with one pair of newly emerged adult of mixed sex were introduced into each jar. The number of deposited eggs on treated and untreated wheat was counted (Sabbour and Shadia, 2015). For each dose, there were three replicates. Oviposition deterrence was calculated by using the discrimination quotient (DQ).

$\mathrm{DQ}=$ (number of eggs on control seeds - number of eggs on treated seeds)/total number of eggs on control and treated seedsPercentage of reduction in oviposition was calculated by the formula:

$\%$ of reduction in oviposition $=\mathrm{DQ} \times 100$

\section{Repellent assay}

According to McDonald et al. 1970 Petri dishes $(9 \mathrm{~cm}$ in diameter) were used to confine insects during the experiment. Filter paper with a $9 \mathrm{~cm}$ diameter was cut two halves and $1 / 2 \mathrm{ml}$ of each concentration was applied separately to one half of the filter paper as uniformly as possible with a micropipette. The other half (control) was treated with $1 / 2 \mathrm{ml}$ of a water. Both of the treated half and the control half were then air-dried to evaporate completely. A full disc was carefully remade by attaching the tested half to the control half with tape. Care was taken so that the attachment did not prevent free movement of insects from the one half to another, but the distance between the filter paper halves remained sufficient to prevent seepage of test sample from one half to another. Ten insects of Tribolium castaneum were released in the center of each filter paper disc and a cover was placed over the Petri dish. Three replicates were used. Counts of the insects present on each strip were made after $7 \mathrm{~h}, 12 \mathrm{~h}, 24 \mathrm{~h}$, and $48 \mathrm{~h}$. For all insects, concentration of $50 \mathrm{ppm}, 100 \mathrm{ppm}$, and $150 \mathrm{ppm}$ of malathion, silver nanoparticles, and the mixture of malathion and silver nanoparticles were used.

The repellency percentage can be calculated by using the formula:

$$
\begin{gathered}
\text { \%repellency }=(\mathrm{Nc}-5) \times 20 \% \\
\mathrm{Nc}=\text { repellency record }
\end{gathered}
$$

\section{Antifeedant assay}

Flour discs were prepared according to the method of Xie et al. (1996). In brief, $10 \mathrm{~g}$ of flour was mixed with $50 \mathrm{ml}$ of distilled water. Using a micropipette, $200 \mu \mathrm{l}$ of the prepared suspension was poured, and it is converted to a tablet-like discs. The flour discs were air dried. Then, the flour discs were treated with $50 \mathrm{ppm}, 75 \mathrm{ppm}$, and $100 \mathrm{ppm}$ of the silver nanoparticles. The same concentration of the malathion and mixed suspension of the malathion and the silver nanoparticles were also be used to treat the flour discs. Discs to which only the solvents had applied were used as the control. Tribolium castaneum adults were starved for $48 \mathrm{~h}$ prior to the experiments. In each container, 2 flour discs carrying the same dose and 10 starved adults were placed. The weight of the flour discs, insects and the plastic containers were separately measured and recorded at the beginning and at the 3 days after the start of the experiment. The experiment was replicated three times. The nutritional status was calculated according to Huang et al. 2000.

$$
\text { Relative growth rate }(\mathrm{RGR})=(\mathrm{A}-\mathrm{B}) /(\mathrm{B} \times \text { day })
$$

Where $A$ is the weight of the live insects on the third day $(\mathrm{mg}) /$ number of insects on the third day, B is the original weight of the insects $(\mathrm{mg}) /$ original number of the insects 


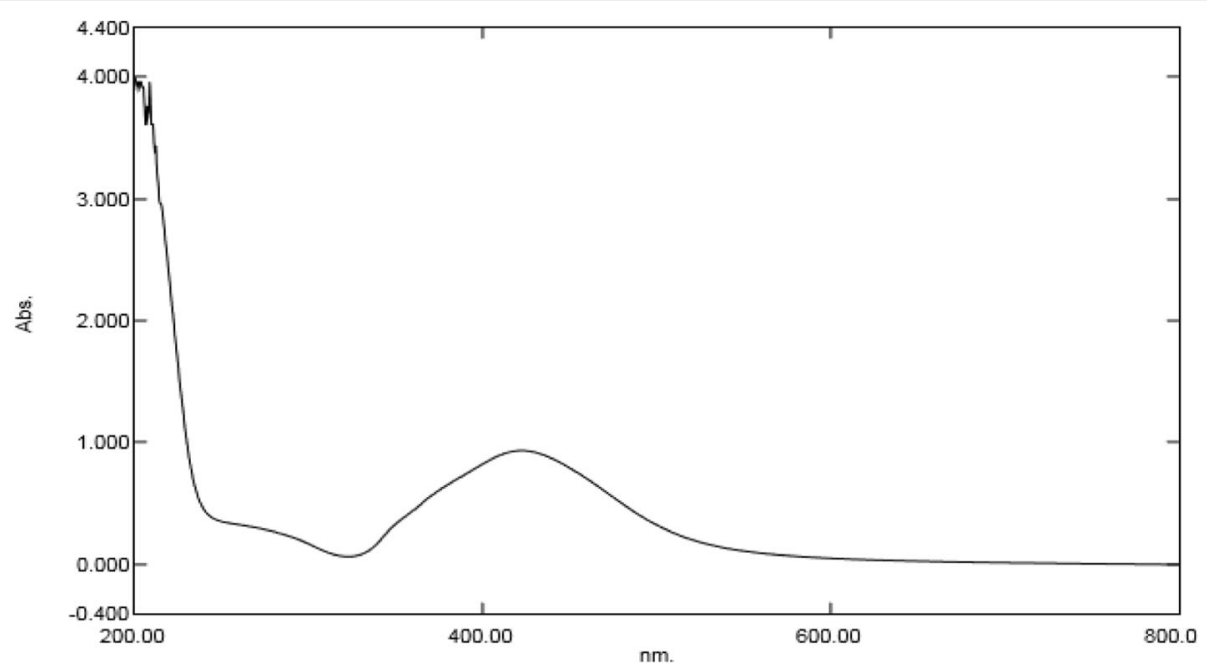

Fig. 1 UV spectrum of colloidal solution of silver nanoparticles

Relative consumption rate $(\mathrm{RCR})=\mathrm{D} /(\mathrm{B} \times$ day $)$

Where $D$ is the biomass ingested (mg)/number of live insects on the third day

Efficacy of conversion of ingested food (ECI\%)

$$
=\mathrm{RGR} \times \mathrm{RCR} \times 100
$$

Feeding deterrence index $(\mathrm{FDI} \%)=[(\mathrm{C}-\mathrm{T} / \mathrm{C}] \times 100$

Where $C$ is the food consumption in control discs (mg) and $T$ is the food consumption in treated discs (mg), for antifeedant activity.

\section{Statistical analysis}

SPSS 20 version was used for the determination of $\mathrm{LC}_{50}$, $\mathrm{LC}_{90}$ in probit analysis (lethal concentration causing 50\% and 90\% mortality), ANOVA, mean, standard deviation, and chi-square test.

\section{Results and discussion}

\section{Characterization of silver nanoparticles}

The colloidal solution turned pale yellow color indicating that the silver nanoparticles were formed in the reaction mixture. The color of the solution was due to the excitation of surface plasmon vibration in the silver nanoparticles. The UV-Vis spectroscopic observations indicate that colloidal solution of silver nanoparticles exhibit an intense absorption peak due to the surface plasmon around $422 \mathrm{~nm}$ which really indicates the formation of silver nanoparticles (Fig. 1). Chemically synthesized silver nanoparticles showed a strong absorbance peak at $428 \mathrm{~nm}$. Similar kind of results was also observed (Thangapandiyan and Prema, 2012). The X-ray

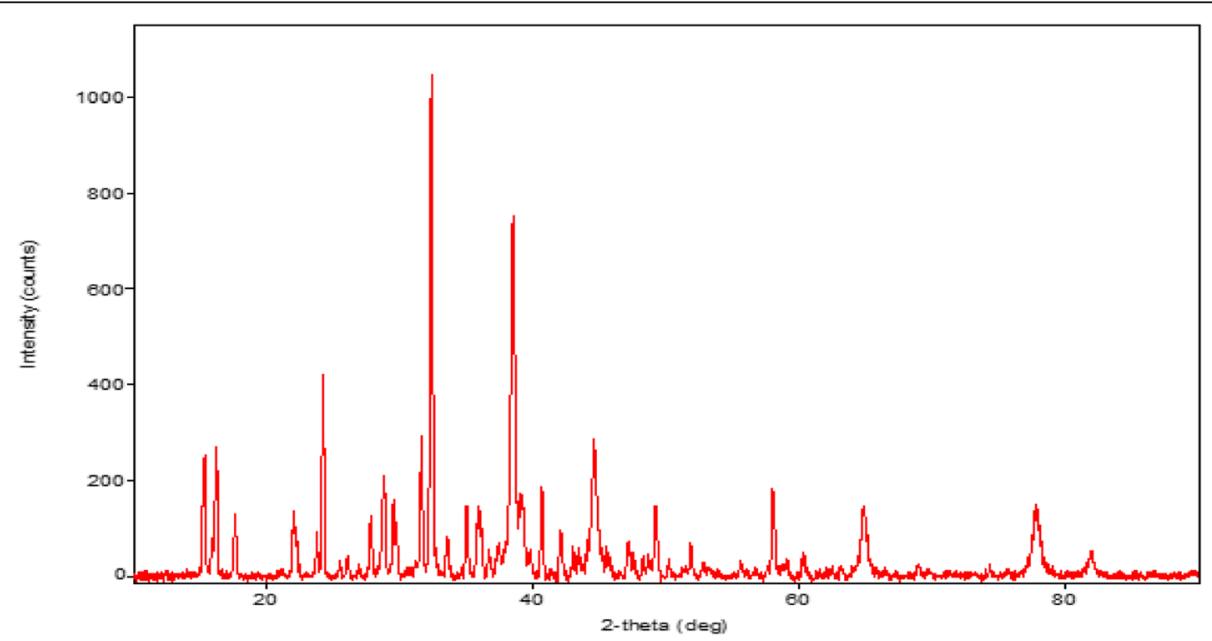

Fig. 2 X-ray diffractogram of chemically synthesized silver nanoparticles 


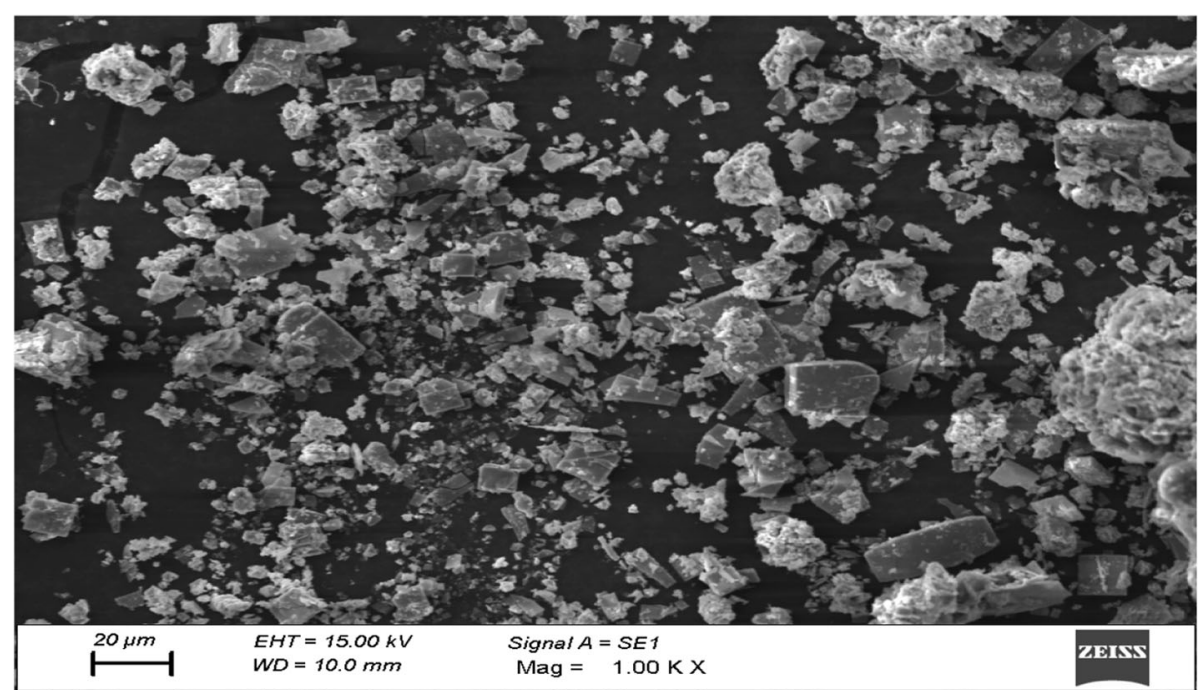

Fig. 3 Scanning electron micrograph of silver nanoparticles

diffraction of silver nanoparticles is depicted in Fig. 2. The intensive diffraction peak at $2 \theta$ value of $38.21^{\circ}$ from the (111) lattice plane of face centred cubic (fcc) unequivocally indicates that the particles are made of pure silver. Three additional bands were observed at $44.49^{\circ}$, $64.75^{\circ}$, and $77.67^{\circ}$ which correspond to the (200), (220), and (311) planes of silver (respectively). The Bragg's peak position and their intensities were compared with standard JCPDS files. The result showed that the particles were spherical and cubic nature. The size of the silver nanoparticles was found to be $27 \mathrm{~nm}$. The characteristic main diffraction peak at $2 \theta=38.08^{\circ}$ confirmed that the

Table 1 Size of silver nanoparticles fabricated by chemical reduction method

\begin{tabular}{ll}
\hline S. no. & Particle size of the silver nanoparticles $(\mathrm{nm})$ \\
\hline 1 & 28.41 \\
2 & 16.20 \\
3 & 20.24 \\
4 & 32.40 \\
5 & 16.20 \\
6 & 28.41 \\
7 & 42.44 \\
8 & 42.44 \\
9 & 16.20 \\
10 & 20.24 \\
11 & 28.41 \\
12 & 32.40 \\
Total & 323.99 \\
Mean & 26.99 \\
Standard deviation & 9.29 \\
\hline
\end{tabular}

particle is made up of pure silver (Krishnakumar et al. 2016). Van Dong et al. 2012 reported the X-ray diffraction of chemical mediated silver nanoparticles exhibit remarkably intensive diffraction peak at $2 \theta=38.1^{\circ}$. The present findings are very much closer to the earliest reports. Scanning electron micrograph of synthesized silver nanoparticles revealed that the particle were more or less cubical and spherical in nature (Fig. 3). The size of the silver nanoparticles fabricated by chemical reduction method is given in Table 1 . The percent frequency distributions of the obtained silver nanoparticles are given in Table 2. The synthesized AgNPs showed individual particles as well as agglomerated particles. The agglomeration is due to the intermolecular interaction such as Van der Waals force. The similar kind of morphology of silver nanoparticle with some irregular particles was also reported (Basavaraj et al. 2012). Energy dispersive spectra of silver nanoparticles showed a strong signal at $3 \mathrm{keV}$ in the silver region and this confirmed the presence of silver nanoparticles (Fig. 4). The elemental analysis revealed that the silver was a major constituent, and it contains 79.1\%. Maribel et al. 2009 synthesized silver nanoparticles by chemical reduction method and observed a strong peak at $3.40 \mathrm{keV}$ at the silver region.

\section{Mortality tests}

The mortality of Tribolium castaneum increased with increasing concentrations of the tested samples. Data revealed that $T$. castaneum was more susceptible to the mixed suspension of the silver nanoparticles and the malathion. The mortality rate of the $T$. castaneum increased gradually with an increase in the exposure period. On the ninth day of observation, the combination of the malathion and the silver nanoparticles 
Table 2 Frequency distribution of silver nanoparticles size (nm)

\begin{tabular}{lllll}
\hline Silver nanoparticles size $(\mathrm{nm})$ & Tally marks & Frequency & Relative frequency & Percent relative frequency (\%) \\
\hline 28.41 & 111 & 3 & $3 / 12=0.25$ & $0.25 \times 100=25$ \\
16.20 & 111 & 3 & $3 / 12=0.25$ & $0.25 \times 100=25$ \\
20.24 & 11 & 2 & $2 / 12=0.17$ & $0.17 \times 100=17$ \\
32.40 & 11 & 2 & $2 / 12=0.17$ & $0.17 \times 100=17$ \\
42.44 & 11 & 2 & $2 / 12=0.17$ & $0.17 \times 100=17$ \\
Total & 12 & 12 & $12 / 12-1.0$ & $1.00 \times 100=100$
\end{tabular}

shows $100 \%$ mortality at the highest concentration. The silver nanoparticles show $75 \%$ mortality at the concentration of $50 \mathrm{mg}$ and the malathion shows $95 \%$ mortality. The $\mathrm{LC}_{50}$ and $\mathrm{LC}_{90}$ values of all the tested samples were illustrated in Table 3. It is known that the increased concentration of the malathion can be hazardous to the human and the environment. So the mixing of the silver nanoparticles to the malathion can be effective in killing the insects as well as the lesser concentration of malathion can be used in the mixed suspension. The data were analyzed using chi-square test, and it is significant at 0.15 level. Previous researches have already confirmed that the nanoparticles can be used in the preparation of new formulation like pesticides, insecticides, and insect repellents (Barik et al. 2008; Gabhiye et al., 2009;). The nanoparticles such as silver nanoparticles, aluminium oxide, zinc oxide, and titanium oxide have the insecticidal activity against the storage pest Sitophilus oryzae. Silver nanoparticles achieved $90 \%$ mortality (Goswami et al. 2010). The biogenic as well as the chemical synthesized silver nanoparticles has the insecticidal activity (Usha Rani et al. 2016).

\section{The ovipositional deterrent effect}

Ovipositional deterrent of three samples, silver nanoparticles, malathion, and its combination at the concentration of $50 \mathrm{ppm}$ are presented in Table 4. The results revealed that the highest reduction in the oviposition was brought by the mixed suspension of the malathion and the silver nanoparticles (71.5\%) followed by

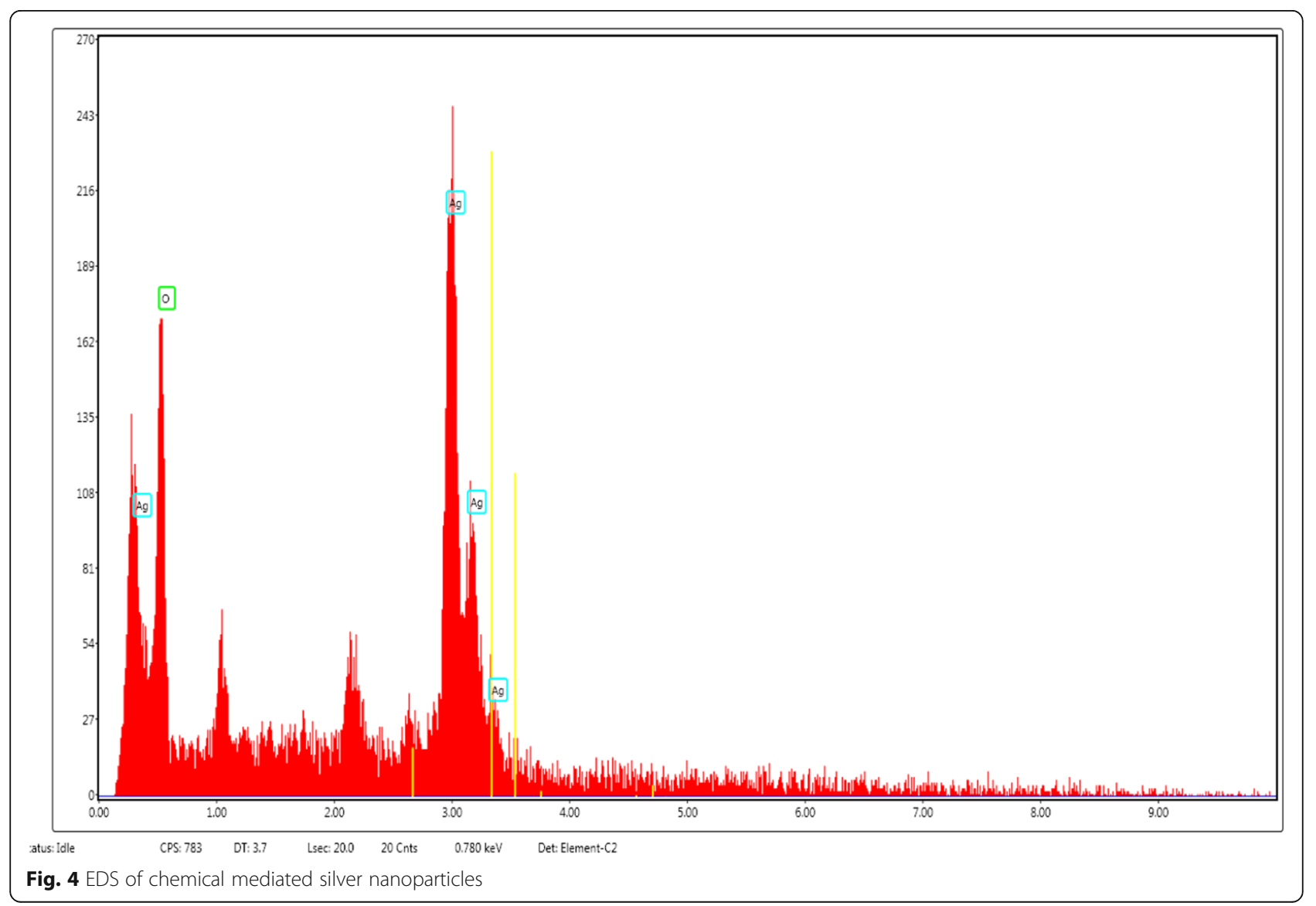


Table 3 Probit analysis for the data on adult mortality of Tribolium castaneum treated with silver nanoparticles, malathion and its combination at 95\% confidence limit

\begin{tabular}{|c|c|c|c|c|c|c|c|c|}
\hline \multirow[t]{3}{*}{ Days } & \multirow{2}{*}{\multicolumn{3}{|c|}{$\begin{array}{l}\text { Mean \%mortality } \\
\text { Concentration }\end{array}$}} & \multirow[t]{3}{*}{$\mathrm{LC}_{50}$} & \multirow[t]{3}{*}{$\mathrm{LC}_{90}$} & \multirow{3}{*}{$\begin{array}{l}\text { Chi- } \\
\text { square } \\
\text { value }\end{array}$} & \multirow{3}{*}{$\begin{array}{l}P \\
\text { value }\end{array}$} & \multirow[t]{3}{*}{ SE } \\
\hline & & & & & & & & \\
\hline & 12.5 & 25 & 50 & & & & & \\
\hline \multicolumn{9}{|c|}{$\operatorname{AgNP}(\mathrm{mg})$} \\
\hline First day & 10 & 15 & 25 & 92.25 & 173.36 & 0.04 & 0.82 & 0.19 \\
\hline Third day & 15 & 30 & 45 & 53.94 & 114.11 & 1.48 & 0.12 & 0.17 \\
\hline Fifth day & 25 & 45 & 60 & 36.84 & 92.41 & 2.22 & 0.13 & 0.10 \\
\hline Seventh day & 30 & 60 & 70 & 25.56 & 75.80 & 7.11 & 0.00 & 015 \\
\hline Ninth day & 45 & 65 & 75 & 13.72 & 77.01 & 2.31 & 0.12 & 0.1 \\
\hline
\end{tabular}

\begin{tabular}{lllllllll}
\multicolumn{10}{c}{ Malathion $(\mu \mathrm{l})$} \\
First day & 15 & 25 & 40 & 61.78 & 125.85 & 0.33 & 0.56 & 0.17 \\
Third day & 25 & 40 & 55 & 42.24 & 105.57 & 0.91 & 0.03 & 0.16 \\
Fifth day & 45 & 50 & 65 & 22.94 & 115.34 & 0.08 & 0.77 & 0.15 \\
Seventh day & 50 & 60 & 75 & 11.83 & 83.60 & 0.03 & 0.05 & 0.15 \\
Ninth day & 65 & 75 & 95 & 4.287 & 50.90 & 0.18 & 0.14 & 0.15
\end{tabular}

Combination of AgNP and malathion ( $\mu$ l)

\begin{tabular}{lllllllll} 
First day & 15 & 30 & 25 & 140 & 334.33 & 5.42 & 0.21 & 0.03 \\
Third day & 40 & 45 & 65 & 29.07 & 102.26 & 0.29 & 0.45 & 0.16 \\
Fifth day & 55 & 65 & 80 & 5.44 & 72.84 & 0.17 & 0.22 & 0.15 \\
Seventh day & 60 & 80 & 85 & 6.500 & 57.77 & 0.69 & 0.05 & 0.15 \\
Ninth day & 70 & 90 & 100 & 4.714 & 24.32 & 0.23 & 0.12 & 0.27 \\
\hline
\end{tabular}

Significant $P<0.15$; Not significant $P>0.15$

malathion (45.11\%). The silver nanoparticle shows the $32.29 \%$ oviposition deterrency. The discrimination quotient (DQ) values represent ovipositional deterrency. The DQ values of the present study are $0.55,0.17$, and 0.29 . Since the values are obtained in positive, it is presumed that all the samples were having promising oviposition deterrency. The DQ values indicated the efficiency of oviposition deterrence property (Messina Renwick and Renwick, 1987). Hence, it has confirmed ovipositional deterrency. The egg production of $T$. castaneum was highly suppressed by nano diatomaceous (Sabbour and Shadia, 2015). The reduction in the egglaying clearly indicates that the nanoparticles can control the population growth and the progeny. The declines in the oviposition at higher doses have been attributed to the interruption of vitellogenesis and damage to the egg chamber (Pandey and Khan, 1998). Vanmathi et al. 2010 stated that the oviposition deterrency may be due to the changes induced in physiology and behavior of the insect. The compounds which have the oviposition deterrent effect can also have an impact on hormonal imbalance and reproductive physiology of insects (Rehman et al. 2009).

\section{Repellent assay}

Repellent activity of synthesized silver nanoparticles, malathion, and the mixed suspension of silver nanoparticles and malathion were tested against the $T$. castaneum. The insects are repelled by the tested samples. The data pertaining to the repellent activity were presented in Table 5 . Highest level of repellency was observed at second hour of exposure of insects at all tested samples. Then, there was a decline in the repellency. The repellency increased with concentration and decreased with time. Only the mixed suspension of silver nanoparticles and malathion at higher concentration shows $100 \%$ percentage repellency throughout the experiment. The entire tested samples at high concentration show more $50 \%$ repellency percentage. The values were statistically significant at 0.15 level. The insecticidal activity of polyethylene glycol (PEG)-coated nanoparticles loaded with garlic essential oil were tested against adult Tribolium castaneum. The essential oils have repellent activity against $T$. castaneum and $L$. bostrychophila (Guo et al. 2016).

\section{Antifeedant assay}

The RGR, RCR, ECI, and FDI values of T. castaneum adults fed the flour discs along with the different concentrations of silver nanoparticles alone, malathion alone, and its mixed suspension are given in the Table 6 .

Relative growth rate and relative consumption rate decrease with increase in the concentration. The RGR and the RCR index are very much reduced at the concentration of $100 \mathrm{ppm}$ of the mixed suspension of the malathion and the nanoparticles $(0.02 \mathrm{mg} / \mathrm{mg} /$ day, 0.11 $\mathrm{mg} / \mathrm{mg} /$ day, respectively). The synthesized silver nanoparticles at $50 \mathrm{ppm}$ show the RGR and RCR values 0.31 $\mathrm{mg} / \mathrm{mg} /$ day and 0.49 which is lower than the control. The RGR and RCR index of the malathion shows higher values when compared to the mixed suspension of AgNPs and malathion. The one-way ANOVA analysis of

Table 4 Ovipositional deterrent assay of Tribolium castaneum treated with silver nanoparticles, malathion, and its combination

\begin{tabular}{lllll}
\hline $\begin{array}{l}\text { Treatment } \\
(50 \text { ppm) }\end{array}$ & No. of eggs in treated & No. of eggs in control & Oviposition reduction (\%) & DQ \\
\hline Malathion & $18.66 \pm 0.57$ & 34 & 45.11 & 0.29 \\
AgNP & $24.00 \pm 1.00$ & 34 & 32.29 & 0.17 \\
Malathion + AgNP & $09.66 \pm 1.52$ & 34 & 71.5 & 0.55 \\
\hline
\end{tabular}


Table 5 Repellent activity of Tribolium castaneum against silver nanoparticles, malathion, and its combination

\begin{tabular}{|c|c|c|c|c|c|c|c|c|c|}
\hline \multirow{2}{*}{$\begin{array}{l}\text { Name of the } \\
\text { sample }\end{array}$} & \multirow{2}{*}{$\begin{array}{l}\text { Concentration } \\
\text { (ppm) }\end{array}$} & \multirow{2}{*}{$\begin{array}{l}\text { No. of } \\
\text { insect } \\
\text { used }\end{array}$} & \multicolumn{5}{|c|}{$\%$ repellency $(\mathrm{Nc}-5) \times 20 \%$} & \multirow{2}{*}{$\begin{array}{l}\text { Chi- } \\
\text { square } \\
\text { value }\end{array}$} & \multirow{2}{*}{$\begin{array}{l}P \\
\text { value }\end{array}$} \\
\hline & & & Second hour & Fourth hour & Sixth hour & Eight hour & Tenth hour & & \\
\hline \multirow[t]{3}{*}{ AgNP } & 150 & 10 & 93.2 & 73.2 & 40 & 26 & 53.2 & 59 & .14 \\
\hline & 100 & 10 & 66.6 & 26 & 13.2 & 73.2 & 40 & 107 & .09 \\
\hline & 50 & 10 & 60 & 26 & 26 & 46 & 46.6 & 35.53 & 0.00 \\
\hline \multirow[t]{3}{*}{ Malathion } & 150 & 10 & 86.6 & 86.6 & 100 & 73.2 & 53.2 & 33.28 & 0.00 \\
\hline & 100 & 10 & 40 & 20 & 20 & 6.6 & 6.6 & 4.47 & 0.21 \\
\hline & 50 & 10 & 33.2 & 13.2 & 20 & 6.6 & 6.6 & 8.05 & 0.45 \\
\hline \multirow[t]{3}{*}{ AgNP+ malathion } & 150 & 10 & 100 & 100 & 100 & 100 & 100 & 00 & 0.00 \\
\hline & 100 & 10 & 100 & 80 & 100 & 100 & 100 & 56.35 & 0.00 \\
\hline & 50 & 10 & 80 & 60 & 46.6 & 33.2 & 80 & 15 & 0.24 \\
\hline
\end{tabular}

Significant $P<0.15$; Not significant $P>0.15$, Nc-Repellency Record

relative growth rate and relative consumption rate of $T$. castaneum were statistically significant at the different concentrations of tested samples $(F=11.35 ; P=0.003, F$ $=11.479 ; P=0.003)$. The reduction in these values clearly indicates that the food consumption by the $T$. castaneum is greatly reduced as it affects the growth rate of the adult insect. Similar to the RGR trend, the reduction rate of ECI \% increased with the increasing sample concentration. The ECI \% of the mixed suspension of AgNPs and malathion at the concentration of $100 \mathrm{ppm}$ shows $22.3 \%$ which is the lowest ECI\% when compared to the other tested samples. The reduction in the ECI\% is due to the inability of conversion of the biomass ingested which clearly indicate that the combination of AgNPs have the antifeedant activity. The one-way ANOVA analysis of efficacy of conversion of ingested food $T$. castaneum revealed that it was statistically significant at the different concentrations of tested samples $(F=4.021 ; P=0.05)$. The FDI values increased with increase in the concentration. The mixed suspension of AgNPs and malathion at the concentration of $100 \mathrm{ppm}$ shows high FDI\% (69.76\%). The FDI\% of synthesized silver nanoparticles at low concentration is $27.32 \%$. The one-way ANOVA analysis of feeding deterrence Index of T. castaneum revealed that it was significantly increased at the different concentrations of tested samples $(F=29.756 ; P=0.00)$. The reduction in the ECI and the increase in the FCI of the mixed suspension of AgNPs and the malathion has a considerable role in the postingestive toxicity. Euphorbia hirta mediated silver nanoparticles have the antifeedant activity against Helicoverpa armigera. Decreased food utilization efficiency measures (ECI and ECD) and concomitant decreased in the level of digestive enzymes profiles in the midgut after the treatment indicate that nanoparticle administration affected gut physiology of insects (Durga et al. 2014).

The AgNPs can interfere with copper transport into cells. They are toxic to the insects because they create a deficiency of copper. The protein portion of the enzymes is produced normally, but they are less active because the copper is not incorporated into an enzyme active site, possibly due to copper availability (Armstrong et al., 2013). Management of stored grain pests stands traditionally on use of synthetic insecticides and long-term application of these chemicals develops resistance to pesticides. In recent years, nanotechnology has received much attention for controlling pathogens in agriculture (Eleka et al. 2010). The obtained results clearly indicate that the silver nanoparticles can be used as the best alternative for the insect pest management. As the insects

Table 6 Antifeedant activity of Tribolium castaneum against silver nanoparticles, malathion, and its combination

\begin{tabular}{|c|c|c|c|c|c|c|c|c|c|c|c|c|}
\hline \multirow{2}{*}{$\begin{array}{l}\text { Conc } \\
\text { (ppm) }\end{array}$} & \multicolumn{3}{|c|}{ RGR (mg/mg/day) } & \multicolumn{3}{|c|}{ RCR (mg/mg/day) } & \multicolumn{3}{|l|}{$\mathrm{ECl} \%$} & \multicolumn{3}{|l|}{ FDI\% } \\
\hline & $\mathrm{M}$ & AgNP & $M+A g N P$ & $\mathrm{M}$ & AgNP & $M+A g N P$ & $M$ & AgNP & $M+A g N P$ & $M$ & AgNP & $M+A g N P$ \\
\hline Control & 0.33 & 0.33 & 0.33 & 0.48 & 0.48 & 0.48 & 69.50 & 69.50 & 59.50 & 0 & 0 & 0 \\
\hline 50 & 0.25 & 0.31 & 0.20 & 0.40 & 0.49 & 0.37 & 63.18 & 63.28 & 53.72 & 34.65 & 27.32 & 41.15 \\
\hline 75 & 0.13 & 0.23 & 0.09 & 0.26 & 0.38 & 0.20 & 50.95 & 60.62 & 46.88 & 46.98 & 39.87 & 54.75 \\
\hline 100 & 0.05 & 0.16 & 0.02 & 0.17 & 0.27 & 0.11 & 32.38 & 58.06 & 22.3 & 59.72 & 45.10 & 69.76 \\
\hline
\end{tabular}

Note: $R G R$ relative growth rate; $R C R$ relative consumption rate; $E C l$ efficacy of conversion of ingested food; $F D I$ feeding deterrence index; $M$ malathion; $A g N P$ silver nanoparticles 
are being resistant to the various chemical insecticides, the mixing of nanoparticles can provide a better way to control the storage pests.

\section{Conclusion}

Agriculture is the backbone of most developing countries. The pests and beetles are the major threat to the field of agriculture and the post-harvesting grain crops, as they increase the risk of damages. They affect the quality as well as the quantity of the grains. Tribolium castaneum is the major beetle which infests the storage grains. Nanotechnology plays an important role in pest control management. In the present study, results on the bioassay including the mortality tests, antifeedent tests, ovipositional deterrency, and the repellent activity reveal that the malathion along with silver nanoparticles show highest pesticidal activity against Tribolium castaneum. As the beetles improve their insecticide resistance to the commercial synthetic insecticide, the use of silver nanoparticles can be very effective against the beetles and the pests which is a major threat to the agricultural crops as well as the storage grains. In conclusion, the present findings clearly indicate that the silver nanoparticles possess the capabilities of being a good candidate in the search of an alternative for the damages caused by the beetles.

\section{Abbreviations \\ AgNPs: Silver nanoparticles; ECl: Efficacy of conversion of ingested food: EDS: Energy dispersive spectroscopy; FDI: Feeding deterrence index; M: Malathion; Ppm: Parts per million; RCR: Relative consumption rate; RGR: Relative growth rate; SEM: Scanning electron microscopy; XRD: X-ray diffraction pattern}

\section{Acknowledgements}

The authors greatly acknowledge the Department of Zoology, PSG College of Arts and Science for the facilities extended towards the research.

\section{Competing of interests}

The authors declare that they have no competing interests.

\section{Authors' contributions}

ASAA performed the experiment and wrote the manuscript. ST was sourced as a research supervisor and designed the work. Both authors read and approved the final manuscript

\section{Funding}

We declare that there are no funding sources.

\section{Availability of data and materials}

All the data and materials presented in the manuscript are the original work of the authors.

\section{Ethics approval and consent to participate}

Not applicable

\section{Consent for publication}

We give our consent to The Editor of The Journal of Basic and Applied

Zoology (Springer) that our manuscript be published in their journal.
Received: 17 April 2019 Accepted: 5 July 2019

Published online: 25 July 2019

\section{References}

Abduz Zahir, A., Bagavan, A., Kamaraj, C., Elango, G., \& Abdul Rahuman, A. (2012). Efficacy of plant-mediated synthesized silver nanoparticles against Sitophilus oryzae. Journal of Biopesticides, 5(Supp), 95-102.

Armstrong, N., Ramamoorthy, M., Lyon, D., Jones, K., \& Duttaroy, A. (2013). Mechanism of silver nanoparticles action on insect pigmentation reveals intervention of copper homeostasis. PLoS One, 8(1), 53186.

Barik, T. K., Sahu, B., \& Swain, V. (2008). Nano-silica- from medicine to pest control. Parasitology Research, 103, 253-258.

Basavaraj, U., Praveenkumar, N., Sibha, S., Rupali, M., \& Balgi, S. (2012). Synthesis and characterization of silver nanoparticles. International Journal of Pharmacy and Biological Science, 2(3), 10-14.

Berhanu, H., \& Emana (2018). Host type and textures on the survival of Tribolium castaneum (Coleoptera: Tenebrionidae) parental and filial generations. Journal of Entomology and Zoology studies, 6(1), 622-626.

Durga devi, G., Murugan K and Panneerselvam, C. (2014). Green synthesis of silver nanoparticles using Euphorbia hirta (Euphorbiaceae) and leaf extract against crop pest of cotton ball worm, Helicoverpa armiger. Journal of Biopesticides, 7(Supp): 54-66.

Eleka, N., Hoffmanb, R., Reshb, U., Ishaayac, R. I., \& Magdassi, S. (2010). Novaluron nanoparticles: Formation and potential use in controlling agricultural insect pests. Colloids and Surfaces A: Physicochemical and Engineering Aspects, 372, $66-72$.

FAO. (1983). Post-harvest losses in quality of food grains. Food and nutrition paper 29, FAO, Rome, Italy, Pp.657-660.

Gabhiye, M., Kesharwani, J., Ingle, A., Gade, A., \& Rai, M. (2009). Fungus mediated synthesis of silver nanoparticles and its activity against pathogenic fungi in combination of fluconazole. Nanomedicine, 5, 282-286.

Goswami, A., Roy, I., Sengupta, S., \& Debnath, N. (2010). Novel applications of solid and liquid formulations of nanoparticles against insect pests and pathogens. Thin Solid Films, 519, 1252-1257.

Guo, S. S., Zhang, W. J., Yang, K., Liang, J. U., You, C. X., Wang, C. F., ... Du, S. S. (2016). Repellence of the main components from the essential oil of Glycosmis lucida Wall. ex Huang against two stored product insects. Natural Product Research, 31(10), 1201-1204. https://doi.org/10.1080/14786419.2 016.1226825 .

Horton, P. M. (1984). Evaluation of South Carolina field strains of certain stored product coleopteran for malathion resistance and pirimiphos-methyl susceptibility. Journal of Agricultural Entomology, 1(1), 1-5.

Huang, Y., Lam, S. L., \& Ho, S. H. (2000). Bioactivity of essential oil from Elletaria cardamomum (L.) Maton. to Sitophilus zeamais Motschulsky and Tribolium castaneum (Herbst). Journal of Stored Products Research, 36(1), 107-117.

Krishnakumar, S., Nanda, A., Dattaray, D., \& Jacob, A. (2016). Characterization of chemical mediated synthesis of silver nanoparticles (Ag-NPs) and their antibacterial efficacy against selected bacterial pathogens. Der Pharmacia Lettre., 8(8), 380-387.

Maribel, G., Jean, D., \& Stephan, G. (2009). Synthesis of silver nanoparticles by chemical reduction method and their antibacterial activity. International Journal of Chemical and Biomolecular Engineering, 2(7), 3.

Marwa Thamer, N., Mahmood, E. A., \& Hussam, E. (2017). The effect of silver nanoparticles on second larval instar of Trogoderma granarium everts (Insecta: Coleoptera: Dermrstidae). International Journal of Science and Nature 8(2), 303-307.

McDonald, L., Guy, R. H., \& Speirs, R. D. (1970). Preliminary evaluation of new candidate materials as toxicants, repellents, and attractants against storedproduct insects. Marketing Research Report of Agriculture, 882, 5.

Messina Renwick, J., \& Renwick, J. A. A. (1987). Oviposition deterrent from eggs of Callosobruchus maculatus: Spacing mechanism or artifact? Journal of Chemical Ecology, 13(1), 219-226.

Mostafa, M., Hemayet, H., Anwar Hossain, M., Pizush, K. B., \& Zahurul Haque, M. (2012). Insecticidal activity of plant extracts against Tribolium castaneum Herbst. Journal of Advanced Scientific Research, 3(3), 80-84.

Muhammad Saqib, A., Javid, I., Mirza Abdul, Q., Muhammad Asad, S., Tayyab, M., \& Sajjad, M. (2018). Preferential influence of wheat varieties (Triticum aestivum L.) on population build-up of aphid (Homoptera: Aphididae) and it natural enemies. Journal of Entomology and Zoology Studies, 6(1), 609-612.

Murawala, P., Tirmale, A., Shiras, A., \& Prasad, B. L. (2014). In situ synthesized BSA capped gold nanoparticles: effective carrier of anticancer drug methotrexate 
to MCF-7 breast cancer cells. Materials Science and Engineering C: Materials for Biological Applications, 34(1), 158-167.

Pandey, S. K., \& Khan, M. B. (1998). Screening and isolation of leaf extract of Clerodendrum siphonanthus and their effects of Callosobruchus chinensis through injection method. Indian. Journal of Toxicology, 6, 57-65.

Parkin, E. A. (1958). A provisional assessment of malathion for stored product insect control. Journal of Science of Food and Agriculture, 9(6), 370-375.

Prakash, A. J., Rao, I., Pasalu, C., \& Mathur, K. C. (1987). Rice Storage and insect pests management, (p. 337). New Delhi: BR Publishing Corporation.

Rehman, J., Jilani, G., Ajab Khan, M., Masih, R., \& Kanvil, S. (2009). Repellent and oviposition deterrent effect of Indigenous plant extracts to peach Fruit fly, Bactrocera zonata Saunders (Diptera: Tephridae). Pakistan Journal of Zoology, 41, 101-108.

Resham, S., Khalid, M. and Kazi, A. G. 2015. Nanobiotechnology in agricultural development. In: Bargh, D., Khan, M., Davies, E. (eds) Plant Omics: The omics of plant science. Springer, New Delhi. https://doi.org/10.1007/97881-322-2172-2_24

Sabbour, M., \& Shadia, E. (2015). Efficacy of Nano-diatomaceous earth against red flour beetle, Tribolium castaneum and confused Flour beetle, Tribolium confusum (Coleoptera, Tenebrionidae) under Laboratory and Storage conditions. Bulletin of Environment, Pharmacology and Life Sciences, 4(7), 54-59.

Sahayaraj, Kitherian. (2017). Nano and Bio-nanoparticles for Insect Control. Research Journal of Nanoscience and Nanotechnology, 7(1):1-9. https://doi. org/10.3923/rinn.2017.1.9

Taghizadeh, R., \& Mohammadkhani, N. (2017). Antifeedent activity of Descurainia sophia and Thuja orientalis extracts against Tribollium casteneum (Coleoptera Tenebroinedae). Journal of Crop Protection, 6(4), 487-495.

Thangapandian, S., \& Prema, P. (2012). Chemically fabricated silver nanoparticles enhances the activity of antibiotics against selected human bacterial pathogens. International Journal of Pharmaceutical Science and Research, 3(5), 1415-1422.

Usha Rani, P., Prasanna Laxmi, K., Vadlapudi, V., \& Sreedhar, B. (2016). Phytofabrication of silver nanoparticles using the mangrove associate, Hibiscus tiliaceus plant and its biological activity against certain insect and microbial pests. Journal of Biopesticides, 9(2), 167-179.

Van Dong, P., Hoang Ha, C., Tran Binh, L., \& Kasbohm, J. (2012). Chemical synthesis and antibacterial activity of novel shaped silver nanoparticles. International Nano Letters, 2(1), 1-9.

Vanmathi, J. S., Padmalatha, C., Ranjith Singh, A. J. A., \& Sudhakar Issac, S. (2010). Efficacy of selected plant extracts on the oviposition deterrent and adult emergence activity of Callosobruchus chinensi F. Global Journal of Science Frontier Research., 10, 12-14.

Xie, Y. S., Bodnaryk, R. P., \& Fields, P. G. (1996). A rapid and simple flour disk bioassay for testing natural substances active against stored product insects. Canadian Entomologist, 128, 865-875.

\section{Publisher's Note}

Springer Nature remains neutral with regard to jurisdictional claims in published maps and institutional affiliations.

\section{Submit your manuscript to a SpringerOpen ${ }^{\circ}$ journal and benefit from:}

- Convenient online submission

- Rigorous peer review

- Open access: articles freely available online

- High visibility within the field

- Retaining the copyright to your article

Submit your next manuscript at $\boldsymbol{\nabla}$ springeropen.com 